Przegląd Narodowościowy / Review of Nationalities • nr 7/2017 • World of Slavs / Świat Słowian

\title{
The essence of true HOMELAND. \\ The ways of understanding the value of the HOMELAND by young Poles from Poland and Ukraine having Polish citizenship or formal adherence to the Polish nation

\author{
Istota prawdziwej OJCZYZNY. \\ Sposoby rozumienia wartości OJCZYZNA przez młodych Polaków z Polski i Ukrainy \\ posiadających polskie obywatelstwo lub formalną przynależność do narodu polskiego
}

Keywords: homeland, Poland, Ukraine, Polish minority

\section{Introduction}

The word "homeland" belongs to the category of concepts that are close to each human being, well known to everyone, but by their multidimensionality, differently defined. Due to the multitude of aspects discussed, starting with historical and cultural content, it is subject to social, ideological and even political disputes leading to the transfer of this seemingly private value to the international level. Understanding this concept is being devalued, transformed. The form of response to this thesis is the volume Language-values-politics: changes in the understanding of names of values in the period of political transformation in Poland: a report on empirical studies ${ }^{1}$ in which

\footnotetext{
1 See: more: J. Bartmiński, Ojczyzna, [in:] Ję zyk - wartości - polityka: zmiany rozumienia nazw wartości w okresie transformacji ustrojowej w Polsce. Raport z badań empirycznych, edit. J. Bartmiński, Lublin 2006, pp. 340-347.
}

Słowa kluczowe: ojczyzna, Polska, Ukraina, mniejszość polska

Wstęp

Słowo „ojczyzna” należy do kategorii tych pojęć, które są bliskie każdemu człowiekowi, powszechnie znane, lecz przez swą wielowymiarowość różnorodnie definiowane. Ze względu na wielość poruszanych aspektów, poczynając od treści historycznych i kulturowych, bywa ono przedmiotem sporów społecznych, ideologicznych, a nawet politycznych prowadzących do przeniesienia tej na pozór prywatnej wartości na poziom międzynarodowy. Rozumienie tego pojęcia ulega dewaluacji, transformacji. Formą odpowiedzi na tę tezę jest tom Język - wartości - polityka: zmiany rozumienia nazw wartości w okresie transformacji ustrojowej w Polsce: raport $z$ badań empirycznych ${ }^{1}$, w którym autorzy porównali opisy wybranych wartości ba-

1 Por. szerzej: J. Bartmiński, Ojczyzna, [w:] Język - wartości - polityka: zmiany rozumienia nazw wartości w okresie transformacji ustrojowej w Polsce.

* Correspondence address: Instytut Studiów Międzynarodowych, ul. Koszarowa 3, budynek 21, 51-149 Wrocław, e-mail: malwina.hopej@uwr.edu.pl. 
the authors compared the descriptions of selected values tested in 1990 and 2000. In this article, going beyond the way set by the team of Jerzy Bartmiński, I would also like to present ways to interpret the term homeland by young Poles. My research group will be Poles living in two states, the Republic of Poland and Ukraine. So far, no such studies have been conducted among representatives of national or ethnic minorities.

The article presents the conceptualization of the term HOMELAND, which is a compilation of the results of surveys conducted in Lvov and Mościska (Mostyska) (April, November 2015) and in Wroclaw and Legnica (May, November 2015). Their aim is to create a specific definition of a cognitive homeland by examining how Poles living in different realities and states understand this concept: whether they value it equally, they identify with their place of residence and finally how the external world within the meaning of the language, cultural community, legal status, affects the perception of this one of the most prominent issues for man. The text consists of two parts: the first will describe the method used in the study of values by a team of linguists working under the guidance of prof. Jerzy Bartmiński, which I used in the preparation of the second part, presenting the research report. danych w roku 1990 i 2000 . W tym artykule, jednocześnie podążając i wykraczając poza drogę wyznaczoną przez zespół Jerzego Bartmińskiego, chciałabym również zestawić sposoby interpretacji terminu ojCzyzna przez młodych Polaków, przy czym moją grupą badawczą będą Polacy zamieszkujący dwa państwa, Rzeczpospolitą Polską i Ukrainę. Dotychczas nie przeprowadzano tego typu badań wśród przedstawicieli mniejszości narodowych czy etnicznych.

Artykuł prezentuje konceptualizację pojęcia OJCZYZNY stanowiącą opracowanie wyników badań ankietowych przeprowadzonych we Lwowie i Mościskach (kwiecień, listopad 2015 r.) oraz we Wrocławiu i Legnicy (maj, listopad 2015 r.). Ich celem jest stworzenie swoistej definicji kognitywnej ojczyzny poprzez sprawdzenie, $\mathrm{w}$ jaki sposób Polacy funkcjonujący w różnych realiach i państwach rozumieją to pojęcie: czy tak samo je wartościują, utożsamiają z miejscem zamieszkania, w końcu jak świat zewnętrzny, w rozumieniu wspólnoty językowej, kulturowej, statusu prawnego, wpływa na sposób postrzegania tej jednej z najistotniejszych dla człowieka kwestii. Tekst składa się z dwóch części: w pierwszej zostanie przedstawiony opis metody zastosowanej w badaniu wartości przez zespół lubelskich lingwistów pracujących pod kierownictwem prof. Jerzego Bartmińskiego, którą posłużyłam się przy opracowywaniu części drugiej, przedstawiającej raport z przeprowadzonych badań.

Raport z badań empirycznych, red. J. Bartmiński, Lublin 2006, s. 340-347. 


\section{Methodological assumptions}

The study was attended by 52 respondents from Ukraine and Poland: high school graduates and students ${ }^{2}$ with a Pole's Card or citizenship of the Republic of Poland, and therefore the most open group, susceptible to cultural diffusion phenomenon of people who in the future will be shaping the policy of both states.

Respondents received a three-part open question sheet, which included the question "What do you think is the essence of a true HOMELAND?", which is the basis of this article, and closed where the hierarchy of given values according to their importance should be drawn, as well as the personal questionnaire. The first part of the questionnaire was developed using the method used by the Lublin linguistic team, in which respondents' answers are

2 Schools and colleges in which surveys were conducted among Poles living in Ukraine: St. Mary Magdalene High School No.10 in Lvov, High School No. 3 in Mościska, Ivan Franko University of Lvov, Lvov Polytechnic National University. Schools and colleges where the surveys were conducted among Poles living in Poland: Jan Hevelius High School No. 5 in Legnica, Wrocław University, Wrocław University of Technology, The General Tadeusz Kościuszko Military Academy of Land Forces in Wrocław.

The choice of Ukrainian cities was dictated by historical and demographic considerations. According to estimates by the Polish Ministry of Foreign Affairs, in Lvov Consular Area covering the Ivano-Frankivsk Oblast, Lwów, Zakarpatski, there are 120150 thousand Poles, and schools in Lvov and Mościska for a long time were the only institutions with Polish language teaching, see: Polska mniejszość narodowa w Lwowskim Okręgu Konsularnym, http:// www.lwow.msz.gov.pl/pl/wspolpraca_dwustronna/ polacy_na_ukrainie/; Okregi konsularne na Ukrainie, http://www.kijow.msz.gov.pl/pl/sprawy_konsularne_i_wizowe/wizy/okregi_kons/okregi_konsularne_na_ukrainie, E. Toczek, Polacy na Białorusi i Ukrainie, Biuro studiów i ekspertyz, "Informacja" No. 599, February 1998, pp. 6-8.

\section{Założenia metodologiczne}

W badaniu udział wzięło po 52 ankietowanych z Ukrainy i Polski: maturzystów i studentów ${ }^{2}$ posiadających Kartę Polaka lub obywatelstwo Rzeczypospolitej Polskiej, a zatem grupa najbardziej otwartych, podatnych na zjawisko dyfuzji kulturowej ludzi, w przyszłości kształtujących politykę obu państw.

Respondenci otrzymali arkusz składający się z trzech części - otwartej, w której znalazło się pytanie: „Co Pani/Pana zdaniem stanowi o istocie prawdziwej oJCZYZNY?" będące bazą tego artykułu, zamkniętej, gdzie należało sporządzić hierarchię podanych wartości według istności, a także kwestionariusza osobowego. Pierwsza część ankiety została opracowana metodą

2 Szkoły i uczelnie, w których przeprowadzono ankiety wśród Polaków mieszkających na Ukrainie: Szkoła Średnia nr 10 im. św. Marii Magdaleny we Lwowie, Ogólnokształcąca Szkoła Średnia nr 3 w Mościskach, Lwowski Uniwersytet Narodowy im. I. Franki, Uniwersytet Narodowy Politechnika Lwowska. Szkoły i uczelnie wyższe, w których przeprowadzono ankiety wśród Polaków mieszkających w Polsce: Liceum Ogólnokształcące nr 5 im. Jana Heweliusza w Legnicy, Uniwersytet Wrocławski, Politechnika Wrocławska, Wyższa Szkoła Oficerska Wojsk Ladowych im. gen. T. Kościuszki.

Wybór ukraińskich miast podyktowany był względami historycznymi oraz demograficznymi. Według szacunków Polskiego Ministerstwa Spraw Zagranicznych, na terenie Lwowskiego Obszaru Konsularnego obejmującego okręgi iwanofrankowski, lwowski, zakarpacki, zamieszkuje 120150 tys. Polaków, szkoły zaś we Lwowie i Mościskach przed długi czas były jedynymi placówkami z polskim językiem nauczania. Polska mniejszość narodowa w Lwowskim Okręgu Konsularnym, http:// www.lwow.msz.gov.pl/pl/wspolpraca_dwustronna/ polacy_na_ukrainie/, Okregi konsularne na Ukrainie; http://www.kijow.msz.gov.pl/pl/sprawy_konsularne_i_wizowe/wizy/okregi_kons/okregi_konsularne_na_ukrainie; E. Toczek, Polacy na Białorusi i Ukrainie, Biuro studiów i ekspertyz, „Informacja" nr 599, luty 1998, s. 6-8. 
texts induced by several-tier analysis, so before the discussion of the results of the survey, the markings at each part of the data will be explained.

Although the combination of the "real homeland" may seem artificial, the use of the adjective "true" in the construction of the question: "What do you think is the essence of the real X?" is intended to induce the modality of duty inducing respondents to describe the characteristics that they believe should have a homeland. and omit those that actually have (factual modality) as well as attempts to avoid stereotypes in speech.

In the first stage, quotations (marked with $\mathrm{W}$ ) should be indicated and separated - bodies of quotations being carriers of individual semantic features. They are then grouped into semantically relative term groups, the so-called. descriptor groups to which descriptors (D) termed "metatags superimposed on semantically identical expressions" are assigned. They are ranked according to the decreasing frequency of citations, with the final report only having descriptors containing a number of expressions equal to or greater than 4. The last symbol used in this study, stereotype indicator (Ws), represents the percentage of descriptors that are assigned the highest number Expressions from the pool of all citations separated from respondents' answers. Higher Ws indicates that the understanding of values is more schematic, stereotypical ${ }^{3}$. The " $N$ " denotes the

3 J. Bartmiński, Zmiany rozumienia nazw wartości w okresie transformacji ustrojowej w Polsce, [in:] Język-wartości - polityka..., pp. 8-15, 24-28. stosowaną przez wspomniany zespół lingwistów lubelskich, w której odpowiedzi respondentów są tekstami wywołanymi podlegającymi kilkustopniowej analizie, dlatego przed omówieniem wyników badań zostaną wyjaśnione oznaczenia znajdujące się przy poszczególnych częściach danych.

Choć połączenie „prawdziwa ojczyzna" może wydawać się sztuczne, zastosowanie w konstrukcji pytania „Co Pani/ Pana zdaniem stanowi o istocie prawdziwego X?” przymiotnika „prawdziwy” ma na celu wywołanie modalności powinnościowej skłaniającej respondentów do opisania cech, które ich zdaniem powinna mieć ojczyzna oraz pominięcia tych, które ma w rzeczywistości (modalność faktualna), jak również próby uniknięcia w wypowiedziach stereotypów.

W pierwszym etapie należy wskazać i wydzielić wyrażenia cytatowe (oznaczone symbolem W) - korpusy cytatów będące nośnikami pojedynczych cech semantycznych. Są one następnie grupowane w zespoły bliskoznaczne semantycznie, tzw. grupy deskryptorowe, którym przypisuje się deskryptory (D) rozumiane jako „metawyrażenia nadbudowane nad wyrażeniami tożsamymi semantycznie". Są szeregowane według malejącej frekwencji wyrażeń cytatowych, przy czym w końcowym raporcie znajdują się jedynie te deskryptory, które zawierają liczbę wyrażeń równą bądź większą od 4. Ostatni symbol stosowany w tym opracowaniu, wskaźnik stereotypowości (Ws), oznacza procentowy udział deskryptorów, którym przypisano największą liczbę wyrażeń z puli wszyst- 
number of respondents, for both states the number is 52. The survey of Poles from Ukraine consists of 188 quotations and 35 descriptors, from Poland respectively 279 and 51. In addition, in the case of surveys collected in Ukraine, this indicator is 31.91, in Poland 22.93. It is therefore lower by less than 9 percentage points, which shows that the respondents in Legnica and Wrocław understand the true HOMELAND in a broader context than the Poles in Lvov and Mościska.

Symbols used for individual descriptors are a category of aspects to which meta expressions have been qualified. The most commonly used aspect of both the citizenship of the Commonwealth and the Pole's card was the locative aspect. The list of aspects used in the development of the material is as follows: psychosocial (A), ontic (B), ethical (E), biological (G), historical $(\mathrm{H})$, ideological (I), cultural (K), locative $(\mathrm{L})$, psychic $(\mathrm{P})$, religious $(\mathrm{R})$, social $(\mathrm{S})$, political $(\mathrm{T})$, national $(\mathrm{X})^{4}$.

4 M. Brzozowska, O przebiegu badań nad zmianami $w$ rozumieniu nazw wartości $w$ latach 19902000, [in:] Język - wartości - polityka..., pp. 38-43. kich cytatów wydzielonych z odpowiedzi respondentów. Wyższy Ws wskazuje, że rozumienie wartości jest bardziej schematyczne, stereotypowe ${ }^{3}$. Symbolem "N" oznaczono liczbę respondentów, w przypadku obu państw liczba ta wynosi 52. Opracowanie ankiet Polaków z Ukrainy zawiera 188 wyrażeń cytatowych i 35 deskryptorów, z Polski odpowiednio 279 i 51. Ponadto w przypadku ankiet zebranych na Ukrainie wskaźnik ten wynosi 31,91 , w Polsce 22,93, zatem jest niższy o niespełna 9 punktów procentowych, co pokazuje, że respondenci z Legnicy i Wrocławia rozumieją prawdziwą oJCZYZNę w szerszym kontekście aniżeli Polacy ze Lwowa i Mościsk.

Symbole używane przy poszczególnych deskryptorach oznaczają kategorię aspektów, do których zakwalifikowano metawyrażenia. Najczęściej używanym aspektem zarówno przez posiadaczy obywatelstwa Rzeczypospolitej, jak i Karty Polaka był aspekt lokatywny. Lista aspektów użytych przy opracowaniu materiału prezentuje się następująco: psychospołeczny (A), bytowy (B), etyczny (E), biologiczny (G), historyczny $(\mathrm{H})$, ideologiczny (I), kulturowy $(\mathrm{K})$, lokatywny $(\mathrm{L})$, militarny $(\mathrm{M})$, psychiczny $(\mathrm{P})$, religijny $(\mathrm{R})$, społeczny (S), polityczny (T), narodowościowy $(\mathrm{X})^{4}$.

3 J. Bartmiński, Zmiany rozumienia nazw wartości w okresie transformacji ustrojowej $w$ Polsce, [w:] Język-wartości - polityka..., s. 8-15, 24-28.

4 M. Brzozowska, O przebiegu badań nad zmianami $w$ rozumieniu nazw wartości $w$ latach 19902000, [w:] Język - wartości - polityka, s. 38-43. 


\section{HOMELAND according to the respondents from Lvov and Mościska $\mathrm{N}=52, \mathrm{~W}=188, \mathrm{D}=35, \mathrm{~W} s=31.91$}

\section{Kraj (L); $34 / 18.09 \%$}

country where I was born/he or she was born/we were born/of birth 9; country in which I grew/you grew 2; country where I live/we live 5; country in which I feel my own family country; the country where you spent your youth; favorite country in which he/she resides; the country in which I live; country to which I often return; country where he grew up; how you can give everything to your country for example your property; here [in the country] I have to keep my rights and obligations; the country I have in my heart; the country you still want to return; the country you miss; the country where you feel like "being in your element"; a country that is good to me; favorite country; the country that you love; the country in which you feels a human being; the country where I do not have to explain to someone what I'm here for

\section{Place (L); $26 / 13.83 \%$}

the place where you grew up; a place you always want to return 2; a place where you always want to come back; the place where you live; the place where a man lives; the place where a man was born 2; the place where I was born; the place I was born; the place where a man wants to die; a place for which one is afraid; man wants the place to be always peaceful here; man wants to be always good at this place; a place where a person got a good education and initial knowledge; the place where I spent most of 0jczyzna według respondentów ze Lwowa

i Mościsk

$\mathrm{N}=52, \mathrm{~W}=188, \mathrm{D}=35, \mathrm{Ws}=31,91$

\section{Kraj (L); 34/18,09\%}

kraj, w którym się urodziłam/urodziłem/urodził/urodzona/urodzenia/urodziliśmy [9] kraj, w którym wyrosłam/wyrosłeś [2]; kraj, w którym mieszkam/mieszkamy [5]; kraj, w którym czuję się swojo, rodzinny kraj; kraj, gdzie spędziłeś swą młodość; ulubiony kraj, w którym zamieszkuje; kraj, w którym żyję; kraj, do którego często wracam; kraj, w którym wychowywał się; jak można oddać wszystko dla swojego kraju na przykład majątek swój; tu [w kraju] ma się dotrzymywać praw i obowiązków; kraj, który mam w sercu; kraj, do którego ciągle chcesz wracać; kraj, za którym tęsknisz; kraj, gdzie czujesz sie jak „ryba w wodzie"; kraj, który jest dla mnie dobry; ulubiony kraj; kraj, który się kocha; kraj, w którym czuje siebie człowiekiem; kraj, w którym nie muszę się ttumaczyć przed kimś, po co tu jestem

\section{Miejsce (L); 26/13,83\%}

miejsce, gdzie ty wyrosłeś; miejsce, do którego zawsze chce się wracać [2]; miejsce, gdzie zawsze chce się wracać; miejsce, gdzie ty mieszkasz; miejsce, gdzie człowiek mieszka; miejsce, gdzie się człowiek urodzit [2]; miejsce, $w$ którym byłam urodzona; miejsce, gdzie zostałam urodzona; miejsce, gdzie człowiek chce umrzeć; miejsce, za które człowiek się boi; człowiek pragnie, aby w tym miejscu było zawsze spokojnie; człowiek pragnie, aby w tym miejscu było zawsze dobrze; miejsce, gdzie człowiek dostał fajne wykształcenie i począt- 
the time; the place where you feel best; the place where I made the first steps; the place where my grandmothers and grandfathers, parents come from; a place where you keep coming back with thoughts and heart; the place where you want your children to live; the place where our home is; the place where our family is; the place where we are raised; the place where we live; you feel it's the only place like this

\section{Birth (G); $17 / 9.04 \%$}

we are its [the land] children; the country in which I was born/he or she was born/ we were born 6; the country in which I am born; the place where a man was born; the homeland in which we were born; the state in which I was born; the place where the man was born; the place where I was born; country of birth; it is where we were born; the place of your birth; the country where I was born

\section{State $(\mathrm{T}) ; 16 / 8.51 \%$}

a state from which one does not want to leave; the state to which you want to return; to love your state; respect your state; each of us has duties to the state; the state of my grandfathers, great-grandparents, etc.; feeling of belonging each person to the specific state; sense of belonging to a certain state; sense of duty towards the state; the state in which I was born; this is the state to which you feel warm; the state to which you feel the desire to live in it; the state you are eager to work with; the state in which we live; the state in which we feel safe; we attach ourselves to it [the state] kowa wiedzę; miejsce, w którym spędziłam większość czasu; miejsce, w którym czuje się najlepiej; miejsce, gdzie zrobiłam pierwsze kroki; miejsce, skąd pochodza moje babcie i dziadkowie, rodzice; miejsce, do którego cały czas powracasz myślami i sercem; miejsce, gdzie chcesz, żeby mieszkaty twoje dzieci; miejsce, w którym jest nasz dom; miejsce, w którym jest nasza rodzina; miejsce, gdzie się wychowujemy; miejsce, gdzie żyjemy; odczuwasz, że to jedyne takie miejsce

\section{Urodzenie (G); $17 / 9,04 \%$}

jesteśmy jej [ziemi] dziećmi; kraj, w którym się urodziłam/urodziłem/urodziliśmy/urodzit [6]; kraj, w którym jestem urodzona; miejsce, gdzie się człowiek urodził; ojczyzna, w której urodziliśmy się; państwo, w którym się urodziŁem; miejsce, gdzie człowiek urodził się; miejsce, $w$ którym byłam urodzona; kraj urodzenia; jest tam, gdzie się urodziliśmy; miejsce Twojego urodzenia; kraj, gdzie się urodziłem

\section{Państwo (T); 16/8,51\%}

państwo, z którego nie chce się wyjeżdżać; państwo, do którego chce się wracać; kochać swoje państwo; szanowaćswoje państwo; każdy z nas ma swoje obowiazki przed państwem; państwo, z którego pochodza moi dziadowie, pradziadowie itd.; uczucie przynależności każdego człowieka do danego państwa; poczucie przynależności do pewnego państwa; poczucie obowiazku wobec państwa; państwo, w którym się urodziłem; jest to państwo, do którego odczuwasz ciepto; państwo, do którego odczuwasz chęć mieszkania w nim; państwo, do którego odczuwasz chęć pracowania; państwo, w którym mieszkamy; państwo, w któ- 


\section{Residence (B); 11/5.85\%}

The country where I live/we live 5; the place where you live/a man lives 2; the homeland we live in; willingness to live in it [state]; the country in which we live; country of residence

\section{Home (B); $9 / 4.79 \%$}

homeland is your family home; in the homeland, there is a family home; family home; my home 2; the home of people who have a common purpose; home of the people who do not give up and do not keep silent; the place where our home is; often our homeland is what we acquired at home;

\section{Family (S); $8 / 4.26 \%$}

we are its [the land] children; it associates with family; family circle; we remember our ancestors; the state where my grandfathers, great-grandparents, etc. come from; could fight my grandfather, great-grandfather or someone close could have fought [for it]; the place where my grandmothers and grandfathers, parents come from; the place where our family is

\section{Returns (B); $6 / 3.19 \%$}

the place that you always wants to come back; the state to which you want to return; the country to which I often return; the country you still want to return; the place that you always wants to come back to; the place where you always want to come back rym czujemy się bezpieczni; przywiązujemy się do niego [państwa]

\section{Zamieszkanie (B); 11/5,85\%}

kraj, w którym mieszkam/mieszkamy [5]; miejsce, gdzie mieszkasz/człowiek mieszka [2]; ojczyzna, w której mieszkamy; chęć mieszkania w nim [państwie]; państwo, w którym mieszkamy; kraj, w którym zamieszkuje

\section{Dom (B); 9/4,79\%}

ojczyzna to twój rodzinny dom; w ojczyźnie jest rodzinny dom; rodzinny dom; mój dom [2]; dom ludzi, którzy maja wspólny cel; dom ludzi, którzy nie poddaja się i nie milczą; miejsce, $w$ którym jest nasz dom; często ojczyzna jest to, co wynieśliśmy z naszego domu

\section{Rodzina (S); $8 / 4,26 \%$}

jesteśmy jej [ziemi] dziećmi; kojarzy się z rodziną; rodzinne koło; pamiętamy o naszych przodkach; państwo z którego pochodza moi dziadowie, pradziadowie itd.; [o nią] mógł walczyć dziadek, pradziadek lub ktoś bliski; miejsce, skąd pochodza moje babcie i dziadkowie, rodzice; miejsce, w którym jest nasza rodzina

\section{Powroty (B); $6 / 3,19 \%$}

miejsce, do którego zawsze chce się wracać; państwo, do którego chce się wracać; kraj, do którego często wracam; kraj, do którego ciagle chcesz wracać; miejsce, do którego zawsze chce się wracać; miejsce, gdzie zawsze chce się wracać 


\section{Attachment (P); 6/3.19\%}

it is something close to the man; feeling of belonging each person to the specific state; the state to which you feel warm; we attach ourselves to it; the place where you spent most of your time; how you can give everything to your country, for example your property

\section{Well-being (P); 6/3.19\%}

when this way of life corresponds to me; a man wants the place to be peaceful and good here; a country that is good to me; a country where I do not have to explain to someone what I am here for; the place where you feel best; you feel that this is the only place and there is no change

\section{Tradition (K); 5/2.66\%}

is associated with tradition; for me this is traditions; we remember traditions; belonging to your traditions; the traditions in which we were raised

\section{Belonging (S); $5 / 2.66 \%$}

I belong to my nation; feeling of belonging each person to the specific state; sense of belonging to a certain state; belonging to your nation; belonging with their traditions

\section{Growing up (B); $4 / 2.13 \%$}

the country you grew up in 2; the country in which he grew up; the place where we are raised

Respondents characterized "true" HOMELAND with 35 descriptive quali-

\section{Przywiązanie (P); 6/3,19\%}

jest dla człowieka czymś bliskim; uczucie przynależności każdego człowieka do danego państwa; państwo, do którego odczuwasz ciepło; przywiazujemy się do niego; miejsce, w którym spędziłeś większość swojego czasu; jak można oddać wszystko dla swojego kraju na przykład majątek swój

\section{Dobre samopoczucie (P); 6/3,19\%}

kiedy ten sposób życia mi odpowiada; człowiek pragnie, aby $w$ tym miejscu było zawsze spokojnie i dobrze; kraj, który jest dla mnie dobry; kraj, w którym nie musze sie tłumaczyć przed kimś, po co tu jestem; miejsce, w którym czuje się najlepiej; odczuwasz, $\dot{z}$ e to jedyne takie miejsce i nie ma zmiany

\section{Tradycja (K); $5 / 2,66 \%$}

kojarzy się z tradycjami; dla mnie to tradycje; pamiętamy o tradycjach; przynalezność do swoich tradycji; tradycje, w jakich zostaliśmy wychowani

\section{Przynależność (S); $5 / 2,66 \%$}

przynależę do swego narodu; uczucie przynależności każdego człowieka do danego państwa; poczucie przynależności do pewnego państwa; przynależność do swojego narodu; przynależność do swoich tradycji

\section{Dorastanie (B); $4 / 2,13 \%$}

kraj, w którym wyrosłeś/wyrosłam [2]; kraj, w którym wychowywat się; miejsce, gdzie się wychowujemy

Respondenci charakteryzowali „prawdziwą" oJCZYZnę za pomocą 35 cech de- 
ties, recognizing that their most important qualities are the country and place, which indicates the identification of this value with the local homeland ${ }^{5}$ or the socalled small homeland restricting its territory to the place of residence of the respondents, as well as separation from the policy sphere (more frequent indication of descriptor country than state). In the group of 22 descriptors which were not assigned at least four expressions, there are among others nation, security, work, history, citizenship. Significantly, these features were more frequently mentioned by the Legnica and Wroclaw inhabitants, and thus were qualified for the final report.

Poles from Lvov and Mościska conceptualized "true" homeland in four ways. First, they identified it with a specific space reduced to: country, place, state, less frequently land and place. I assumed that the understanding of the descriptor "state" is not the same as "country", so the second place in terms of reference frequency is institutional understanding, although I can not unambiguously state whether the meaning differences between the two terms were known to the respond-

5 See more: J. Bartmiński, Językowe podstawy obrazu świata, p. 182.

6 Although the terms "state" and "country" are commonly used interchangeably, there are significant differences between the two. They refer to three areas: the degree of uniqueness of designata, the essence of definitions, the spatial organization. The state is described by a more precise designate than country, for it refers to boundaries and territory. In addition, the state, as a political-legal entity, adopts the full, official naming of entities referring to spatial organization. And common names are attached to the country, understood as an area of cultural importance. See: M. Blacksell, Geografia polityczna, trans. J. Halbersztat, Warszawa 2008, pp. 47-49. skryptorowych, uznając, że jej najistotniejszymi przymiotami są kraj i miejsce, co wskazuje na utożsamianie tej wartości z ojczyzną lokalnąa lub tzw. małą ojczyzną ograniczającą swe terytorium do miejsca, regionu zamieszkania respondentów, a także odseparowanie od sfery polityki (częstsze wskazywanie deskryptoru kraj niż państwo). W grupie 22 deskryptorów, którym nie przypisano co najmniej czterech wyrażeń, znalazły się m.in.: naród, bezpieczeństwo, praca, historia, obywatelstwo. Co istotne, cechy te były częściej wymieniane przez mieszkańców Legnicy i Wrocławia, przez co zostały zakwalifikowane do końcowego raportu.

Polacy ze Lwowa i Mościsk konceptualizowali „prawdziwą" ojCZYZnę na cztery sposoby. Po pierwsze utożsamiali ją z określoną przestrzenią sprowadzoną do: kraju, miejsca, państwa, rzadziej ziemi i miejscowości. Założyłam, że rozumienie deskryptoru „państwo” nie jest tożsame $\mathrm{z}$ „krajem”, dlatego też na miejscu drugim pod względem częstości odwołań znajduje się rozumienie instytucjonalne, aczkolwiek nie mogę jednoznacznie

5 Por. szerzej: J. Bartmiński, Językowe podstawy obrazu świata, s. 182.

6 Choć terminy „państwo” i „kraj” powszechnie używane są zamiennie, istnieją znaczące różnice dzielące oba pojęcia. Sprowadzają się one do trzech obszarów: stopnia jednoznaczności desygnatów, istoty określanych pojęć, szczebla organizacji przestrzennej. Państwo określa desygnat bardziej precyzyjny aniżeli kraj, do niego bowiem odnoszą się pojęcia granice i terytorium. Dodatkowo państwo, jako obiekt polityczno-prawny, przyjmuje pełne, oficjalne nazewnictwo jednostek odwołujących się do organizacji przestrzennej. Z krajem zaś, rozumianym jako obszar posiadający znaczenie nadane przez kulturę, łączy się nazwy potoczne. Zob.: M. Blacksell, Geografia polityczna, tłum. J. Halbersztat, Warszawa 2008, s. 47-49. 
ents and whether they were consciously used. The next place in this list is occupied by the human community, brought here to the dimensions of the family - home, returns, adolescence, or further positions nation, people, friends. The only characteristic referring to the complex of values to which reference was made at least four times, thanks to which it could be presented in this report, was tradition. Descriptors culture and history did not meet this requirement.

\section{Homeland according to respondents from Wrocław and Legnica \\ $\mathrm{N}=52, \mathrm{~W}=279, \mathrm{D}=51$, Ws $=22.93$}

\section{Country (L); $39 / 13.98 \%$}

I do not want to leave it [country]; country of origin; the country to which man feels attached; it is possible to belong to a country; the country where I grew up; It's not just a plain country; every citizen is obliged to take care of his/her country; I am its [country] citizen; I have the nationality of this country; I feel attached to it [country] (emotionally); I know the official language of this country, history, tradition; our country; it is a country that assures us people safety, peace, prosperity, protects us from the war; the country in which I grew up; the country is always together in every situation; it is the country where my family home is located; it is the country in which my loved ones live; the country in which I want to live; the country in which I want to work; I do not want to leave it [country]; the country of my grandparents and parents; the country stwierdzić, czy różnice znaczeniowe obydwu terminów były znane ankietowanym i czy używano ich świadomie. Kolejną lokatę tego zestawienia zajmuje wspólnota ludzka, tutaj sprowadzona do wymiarów rodziny - domu, powrotów, dorastania czy z dalszych pozycji - narodu, ludzi, znajomych. Jedyną cechą odnoszącą się do kompleksu wartości, do której odwoływano się co najmniej cztery razy, przez co mogła zostać zaprezentowana w tym raporcie, była tradycja. Tego wymogu nie spełniły deskryptory kultura oraz historia.

\section{0jczyzna według respondentów \\ z Wrocławia i Legnicy \\ $\mathrm{N}=52, \mathrm{~W}=279, \mathrm{D}=51$, Ws $=22,93$}

\section{1. $\operatorname{Kraj}(\mathrm{L}) ; 39 / 13,98 \%$}

nie chcę z niego [kraju] wyjeżdżać; kraj pochodzenia; kraj, do którego człowiek czuje się przywiązany; jest możliwościa przynależności do jakiegoś kraju; kraj, w którym się wychowałam; to nie tylko zwykły kraj; każdy obywatel ma obowiązek dbać o swój kraj; jestem jego [kraju] obywatelem; posiadam obywatelstwo tego kraju; czuje sie $z$ nim [krajem] związana (emocjonalnie); znam język urzędowy tego państwa, historię, tradycję; nasz kraj; to kraj, który zapewnia nam, ludziom bezpieczeństwo, spokój, dobrobyt, obroni nas przed wojna; kraj $w$ którym się wychowałam; kraj jest zawsze razem $w$ każdej sytuacji; jest krajem, $w$ którym znajduje się mój dom rodzinny; jest krajem, w którym mieszkaja moi bliscy; kraj, w którym chce żyć; kraj, w którym chce pracować; nie chce $z$ niego [kraju] wyjeżdżać; kraj moich dziadków i rodzi- 
which is governed by the rule of law, order, justice; I am part of this country; the country where I live 4; the country in which I was born 2; the country in which I live 4; I love this country; the country I know since birth; I am a full-fledged citizen of this country; this is my country; the country in which hel she works; this is not an ordinary country, it's something more

\section{State $25 / 8.96 \%$}

mountains, rivers, valleys, etc. lying on the territory of the State; respecting, esteeming culture, history, customs and habits in the area (state); it is for me a state in which I feel good; the state in which I live 2; the state of which I am a citizen 2; the state in which I work; the state in which I study; the state from which I will never emigrate; the state with which I am emotionally bound; the state with which I am legally bound by the possession of my citizenship; I feel a connection with the society of this state; the state where my parents live; the state of which I am a citizen; the state to which I belong by citizenship, the same culture, language, tradition; the state in which I live; every citizen wants the state to continue to develop; the state that educated me; the state from which I do not want to leave even though I have no work; the state in which I live; the state with which I am bound by legal ties; the state with which I am emotionally bound; the state in which everyone works for the success of their nation and state in the international arena; the state that has boundaries, territory, government, law, citizens ców; kraj w którym panuje prawo, porzadek, sprawiedliwość; jestem częścia tego kraju; kraj, w którym mieszkam [4]; kraj, w którym się urodziłam [2]; kraj, w którym żyje [4]; kocham ten kraj; kraj, który znam od urodzenia; jestem pelnoprawna obywatelka tego kraju; to mój kraj; kraj, w którym pracuje; to nie jest zwykly kraj, to coś więcej

\section{Państwo $25 / 8,96 \%$}

góry, rzeki, doliny itp. leżace na terenie Państwa; respektowanie, szanowanie kultury, historii, zwyczajów i obyczajów na danym obszarze (państwie); jest dla mnie państwem, w którym dobrze się czuje; państwo, w którym mieszkam [2]; państwo, którego jestem obywatelem [2]; państwo, w którym pracuje; państwo, w którym studiuje; państwo, z którego nigdy nie wyemigruję; państwo, $z$ którym jestem związany emocjonalnie; państwo, z którym jestem zwiqzany prawnie poprzez posiadanie obywatelstwa; czuje związek ze społeczeństwem tego państwa; państwo, w którym mieszkaja moi rodzice; państwo, którego mam obywatelstwo; państwo, do którego przynależe poprzez obywatelstwo, tę sama kulture, język, tradycje; państwo, w którym żyje; każdy obywatel chce, żeby państwo ciagle się rozwijało; państwo, które mnie wyksztatcito; państwo, z którego nie chce wyjeżdżać, mimo że nie mam pracy; państwo, $w$ którym żyje, funkcjonuje; państwo, $z$ którym jestem zwiazana więzia prawna; państwo, $z$ którym jestem związana emocjonalnie; państwo, w którym każdy pracuje na sukces swego narodu i państwa na arenie międzynarodowej; państwo, które ma granice, terytorium, rzad, prawo, obywateli 


\section{Residence (B); 19/6.81\%}

my family lives here too; the country where I live 4; the state in which I live 2; the country in which I want to live; the land where my family and I live; the state where my parents live; I identify with the people living there; the city in which I live; the state in which I live; the place and the house where I live with my relatives and family; the country in which I live 3; the homeland in which I live; the state in which I live, I am functioning

\section{Place (L); $18 / 6.45 \%$}

place of birth; it is the place where man was born; it is the place where a man grew up; the place where our countrymen, Poles live; safe place; the place that I associate with my own home; a place to which I know I can always return; this place is unique in human life; the place you do not leave; all things are sacrificed for it [place]; the place where I come from 2; the place to which I return with thoughts and memories when I am sad; the place where I grow up; the place where I gain my education; the place where I spent the holiday; there are people there [in the place] who respect me, are honest and care about their place; the place where you are happy

\section{Citizen (T); 17/6.09\%}

is for me an identification with the views of the citizens; every citizen is obliged to take care of his/her country; I am its [country] citizen; I feel him/her [citizen] and this is confirmed by law and documents; I feel part of the citizens; the state of which I am a cit-

\section{Zamieszkanie (B); 19/6,81\%}

mieszka tu też moja rodzina; kraj, w którym mieszkam [4]; państwo, w którym mieszkam [2]; kraj, w którym chcę żyć; kraina, gdzie mieszka moja rodzina i ja; państwo ,w którym mieszkaja moi rodzice; utożsamiam sie $z$ narodem tam mieszkajacym; miasto, w którym mieszkam; państwo, w którym żyję; miejscowość i dom, w którym żyję z moimi bliskimi i rodzina; kraj, w którym żyje [3]; ojczyzna, w której mieszkam; państwo, w którym żyję, funkcjonuje

\section{Miejsce (L); $18 / 6,45 \%$}

miejsce urodzenia; jest miejscem, w którym człowiek się urodził; jest miejscem, w którym człowiek dorastał; miejsce, gdzie mieszkaja nasi, Polacy; miejsce bezpieczne; miejsce, które kojarzy mi się z własnym domem; miejsce, do którego wiem, że zawsze moge powrócić; to miejsce wyjątkowe $w \dot{z} y c i u$ człowieka; miejsca, którego się nie opuszcza; poświęca się wszystko dla niego [miejsca]; miejsce, skąd pochodzę [2]; miejsce, do którego powracam myślami i pamięcia, kiedy jest mi smutno; miejsce, w którym dorastam; miejsce, $w$ którym zdobywam wykształcenie; miejsce, w którym spędzałam wakacje; sa w nim [miejscu] ludzie, którzy mnie szanuja, sa uczciwi i dbaja o swoja miejscowość; miejsce, gdzie jesteś szczęśliwy

\section{Obywatel (T); $17 / 6,09 \%$}

jest dla mnie utożsamianiem się z poglądami obywateli; każdy obywatel ma obowiazek dbać o swój kraj; jestem jego [kraju] obywatelem; czuje się nim [obywatelem] $i$ jest to potwierdzone przez prawo i dokumenty; czuję się częścią obywateli; państwo, 
izen; the state of which I am a citizen; citizens do not break the law; I am a good citizen; being a good citizen; every citizen is aware of the law; every citizen cares for his/ her country; every citizen wants the state and citizens to continue to develop; I am a full-fledged citizen of this country; every citizen is a patriot; every citizen will do anything for his/her homeland; the state that has citizens

\section{People (S); $12 / 4.30 \%$}

unity of people; a country that assures us people safety, peace, prosperity, protects us from the war; thanks to it people unite; people love it; good people; there are people there [in the place] who respect me; people are honest; people care about their place; people around you will not hurt you; people were given the same values; people obey the law; people are not criminals

\section{Bonding ( $P) ; 9 / 3.23 \%$}

the country to which man feels attached; is for me an identification with the views of the citizens; I feel attached to it [country] (emotionally); the state with which I am emotionally bound; the state with which I am legally bound by the possession of citizenship; I feel a connection with the society of this state; I identify with the nation living there; I identify myself with a nation inhabiting a given state; I feel connected with the society którego jestem obywatelem; państwo, którego jestem obywatelem; obywatele nie tamia prawa; jestem dobra obywatelka; bycie dobrym obywatelem; każdy obywatel jest świadomy przepisów prawa; każdy obywatel dba o swój kraj; każdy obywatel chce, żeby państwo i obywatele ciagle się rozwijali; jestem petnoprawna obywatelka tego kraju; każdy obywatel jest patriota; każdy obywatel zrobi wszystko dla swojej ojczyzny; państwo, które ma obywateli

\section{Ludzie (S); $12 / 4,30 \%$}

jedność ludzi; kraj, który zapewnia nam, ludziom, bezpieczeństwo, spokój, dobrobyt, obroni nas przed wojna; dzięki niej ludzie się jednocza; ludzie ja kochaja; dobrzy ludzie; sq w nim [miejscu] ludzie, którzy mnie szanuja; ludzie sa uczciwi; ludzie dbają o swoja miejscowość; ludzie wokót ciebie cię nie skrzywdza; ludziom wpojono takie same wartości; ludzie przestrzegaja prawa; ludzie nie sa przestępcami

\section{Przywiązanie (P); $9 / 3,23 \%$}

kraj, do którego człowiek czuje się przywiazany; jest dla mnie utożsamianiem się z pogladami obywateli; czuję się z nim [krajem] związana (emocjonalnie); państwo, $z$ którym jestem związany emocjonalnie; panstwo, z którym jestem związany prawnie poprzez posiadanie obywatelstwa; czuje związek ze społeczeństwem tego państwa; utożsamiam się z narodem tam mieszkajacym; utożsamiam się z narodem zamieszkującym dane państwo; czuję więź ze spoteczeństwem 


\section{Home (B); $7 / 2.51 \%$}

is like home, having its own traditions, charms, culture; the holidays we celebrate at home; is the second home; the place that I associate with my own home; is the country where my family home is located; the home where I live with my family and loved ones; home

\section{Family (S); $7 / 2.51 \%$}

my family lives here too; the country of my grandparents and parents; the land of my ancestors; the land where my family and me live; the state where my parents live; the place and the home where I live with my family; family

\section{Culture (K); $6 / 2.15 \%$}

respecting, esteeming culture; culture; getting to know [birth and upbringing] its culture; my grandparents and parents passed on the culture of this country; the state to which I belong through the same culture; I love this culture

\section{Common good (E); $6 / 2.15 \%$}

I am a good citizen taking care of my only homeland; I care about my state by being a good citizen, obeying the law or paying taxes, every citizen cares for his/her country; people care about their place; everyone works on the success of his/her nation; everyone works on the success of the state on the international stage

\section{8. $\operatorname{Dom}(B) ; 7 / 2,51 \%$}

jest jak dom, mający własne tradycje, uroki, kulturę; święta, które obchodzimy w domu; jest drugim domem; miejsce, które kojarzy mi się z własnym domem; jest krajem, w którym znajduje się mój dom rodzinny; dom, $w$ którym żyje z moją rodziną $i$ bliskimi; dom

\section{Rodzina (S); $7 / 2,51 \%$}

mieszka tu też moja rodzina; kraj moich dziadków i rodziców; kraina, z której pochodza moi przodkowie; kraina, gdzie mieszka moja rodzina i ja; państwo, w którym mieszkaja moi rodzice; miejscowość i dom, $w$ którym żyję z moja rodzina; rodzina

\section{Kultura (K); 6/2,15\%}

respektowanie, szanowanie kultury; kultura; poznajac przy tym [urodzenie i wychowanie] jej kulturę; przekazywali mi [dziadkowie i rodzice] kulturę tego kraju; państwo, do którego przynależe poprzez tę samą kulturę; kocham tę kulture

\section{Dobro wspólne (E); 6/2,15\%}

jestem dobra obywatelka dbajaca o swoja jedyna ojczyznę; dbam o moje państwo poprzez bycie dobrym obywatelem, przestrzeganie prawa czy płacenie podatków; każdy obywatel dba o swój kraj; ludzie dbaja o swoja miejscowość; każdy pracuje na sukces swego narodu; każdy pracuje na sukces państwa na arenie międzynarodowej 


\section{Birth (G); 5/1.79\%}

place of birth; is the place where a man was born; the country in which I was born 2; the country I know since birth

\section{Unity (S); $5 / 1.79 \%$}

this is unity 2; thanks to it people unite; the country is always together in every situation; they [the people] were given the same values

\section{Traditions ( $\mathrm{T}) ; 5 / 1.79 \%$}

traditions; I know the tradition of this state; the state to which I belong by tradition; I know and I care about passing on centuries-old tradition; I love these traditions

\section{History (H); 5/1.79\%}

respecting, esteeming history; history; I know the history of this state; my grandparents and parents told me the history of this country; I know and I care about passing on history

\section{Citizenship (T); 5/1.79\%}

I have the citizenship of this country; I have the citizenship; the state with which I am legally bound by the possession of citizenship; the state of which I am a citizen; the state to which I belong by citizenship

\section{Emigration (B); 5/1.79\%}

I do not want to leave [the country] 2; the place you do not leave; the state from which I will never emigrate; the state from which I do not want to leave even though I have no work

\section{Urodzenie (G): 5/1,79\%}

miejsce urodzenia; jest miejscem, w którym człowiek się urodził; kraj, w którym się urodziłam [2]; kraj, który znam od urodzenia

\section{Jedność (S); $5 / 1,79 \%$}

jest to jedność [2]; dzięki niej ludzie się jednocza; kraj jest zawsze razem $w$ każdej sytuacji; wpojono im [ludziom] takie same wartości

\section{Tradycje (T); $5 / 1,79 \%$}

tradycje; znam tradycję tego państwa; państwo, do którego przynależe poprzez tradycje; znam i dbam o przekazywanie wielowiekowych tradycji; kocham te tradycje

\section{Historia (H); 5/1,79\%}

respektowanie, szanowanie historii; historia; znam historię tego państwa; przekazywali mi [dziadkowie i rodzice] historię tego kraju; znam i dbam o przekazywanie historii

\section{Obywatelstwo (T); $5 / 1,79 \%$}

posiadam obywatelstwo tego kraju; mam obywatelstwo; państwo, z którym jestem zwiazany prawnie poprzez posiadanie obywatelstwa; państwo, którego mam obywatelstwo; państwo, do którego przynależępoprzez obywatelstwo

\section{Emigracja (B); $5 / 1,79 \%$}

nie chcę z niego [kraju] wyjeżdżać [2]; miejsca, którego się nie opuszcza; państwo, z którego nigdy nie wyemigruje; państwo, z którego nie chcę wyjeżdżać, mimo że nie mam pracy 


\section{Belonging (S); $5 / 1.79 \%$}

it is possible to belong to a country; I feel part of the nation - citizens; I am part of this country; the state to which I belong by citizenship, the same culture, language, tradition; the state with which I am bound by the legal bond

\section{Law (T); 5/1.79\%}

the country which is governed by the rule of law, order, justice; citizens do not break the law; observance of the law; every citizen is aware of the law; the state that has the law

\section{Poland (L); 5/1.79\%}

Poland; $m y$ roots are in Poland, here I was born and will die here; I am a good citizen taking care of my only homeland, Poland; even as I leave this country I will have only one - Poland; only Poland

\section{Close people (S); $4 / 1.43 \%$}

where we are, our loved ones; is the country in which my loved ones live; the place and the home where I live with my loved ones; friends

\section{Work (B); $4 / 1.43 \%$}

where our work is; the country in which I work/want to work 2; the state in which I work

\section{Growing up (B); $4 / 1.43 \%$}

the place where a man grew up; the land where [man] grew up; the country where I grew up; the place where I grow up

\section{Przynależność (S); $5 / 1,79 \%$}

jest możliwościa przynależności, do jakiegoś kraju; czuję się częścia narodu - obywateli; jestem częścia tego kraju; państwo, do którego przynależe poprzez obywatelstwo, tę sama kulture, język, tradycje; państwo, $z$ którym jestem związana więzia prawna

\section{Prawo (T); $5 / 1,79 \%$}

kraj, w którym panuje prawo, porządek, sprawiedliwość; obywatele nie tamia prawa; przestrzeganie prawa; każdy obywatel jest świadomy przepisów prawa; państwo które ma prawo

\section{Polska (L); 5/1,79\%}

Polska; w Polsce sq moje korzenie, tu się urodziłem i tu umre; jestem dobra obywatelka dbajacca o swoja jedyna ojczyznę, Polskę; nawet jak wyjadę to ojczyznę będę miat tylko jedna - Polskę; tylko Polska

\section{Bliscy ludzie (S); $4 / 1,43 \%$}

tam, gdzie jesteśmy my, nasi bliscy; jest krajem, w którym mieszkają moi bliscy; miejscowość i dom, w którym żyję z moimi bliskimi; przyjaciele

\section{Praca (B); $4 / 1,43 \%$}

tam, gdzie jest nasza praca; kraj, w którym pracuje/chce pracować [2]; państwo, w którym pracuje

\section{Dorastanie (B); $4 / 1,43 \%$}

miejscem, w którym człowiek dorastał; ziemia, na której [człowiek] się wychował; kraj, w którym się wychowałam; miejsce, w którym dorastam 


\section{Psychic connection (P); 4/1.43\%}

its inhabitants are a great family; I feel emotionally connected to it [country]; the state with which I am attached/emotionally bound 2

\section{Nation (X); $4 / 1.43 \%$}

I feel part of the nation; I identify with the nation living there; I identify myself with a nation inhabiting a given state; everyone works on the success of his/her nation

\section{Commitment, dedication (S); $4 / 1.43 \%$}

I feel I could defend my homeland; people can defend it because they love it; All things are sacrificed for it; For her freedom can even give her life

\section{Security (B); 4/1.43\%}

provides us, people with safety; defends us against the war; safe place; the place where you know that people around you will not hurt you

The respondents in the characterization of the "true" HOMELAND used 279 quotes in 51 descriptors, 27 of them have the number of expressions equal to or greater than 4 , recognizing that the most important expressions describing this concept are the country and the state.

The inhabitants of Wrocław and Legnica, like the Poles from Ukraine, conceptualized HOMELAND in four ways. First and foremost, it was identified with a specific space, as the descriptors of the country, state, place or land indicate. The second way to value is the human community, which refers to citizens, families, relatives,

\section{Więź psychiczna (P); $4 / 1,43 \%$}

jej mieszkańcy sa wielka rodzina; czuję się $z$ nim [krajem] związana emocjonalnie; państwo, z którym jestem związany/zwiazana emocjonalnie [2]

\section{Naród (X); 4/1,43\%}

czuję się częścia narodu; utożsamiam się $z$ narodem tam mieszkającym; utożsamiam się z narodem zamieszkujacym dane państwo; kazdy pracuje na sukces swego narodu

\section{Oddanie, poświęcenie (S); 4/1,43\%}

czuje, że mogłabym tej ojczyzny bronić; ludzie moga jej bronić, bo ja kochają; poświęca się wszystko dla niego [miejsca]; za jej wolność może oddać nawet życie

\section{Bezpieczeństwo (B); 4/1,43\%}

zapewnia nam, ludziom, bezpieczeństwo; obroni nas przed wojna; miejsce bezpieczne; miejsce, gdzie wiesz, że ludzie wokół ciebie cię nie skrzywdza

Respondenci w charakteryzacji „prawdziwej” oJCzyzny użyli 279 cytatów zebranych w 51 deskryptorów, z czego 27 zawierają liczbę wyrażeń równą bądź większą od 4, uznając, że najistotniejszymi wyrażeniami opisującymi to pojęcie są kraj i państwo.

Mieszkańcy Wrocławia i Legnicy, podobnie jak Polacy z Ukrainy, konceptualizowali oJCzyznę na cztery sposoby. Przede wszystkim utożsamiono ją z określoną przestrzenią, o czym świadczą deskryptory kraj, państwo, miejsce czy kraina. Drugim sposobem ujmowania wartości jest wspólnota ludzka odnosząca się do 
nation, and co-residents, and the latter are recorded only once. The conceptualization of the HOMELAND is also reduced to a complex of values understood as culture, history, tradition, and more rarely language. The respondents also used words referring to descriptors qualified as institutional understanding: state, citizenship, law, and more rarely power.

From the set of 24 descriptors, which due to the sparse number of expressions are not included in this report, it is worth to note the returns, well-being mentioned by the Poles from Lvov and Mościska, as well as patriotism, language, society to which quotes excluded from the induced texts gathered in Ukraine do not refer to.

\section{Features attributed to HOMELAND in terms of aspect. Profiles of the homeland}

For the respondents, the most important aspect of the idea of the "true" HOMELAND was the locative sphere, although in the case of Poles from Poland, this image is linked to the political dimension, as evidenced by the slight differences between the two most significant aspects (5.02 percentage points). The percentage of citations of the various aspects presented in figure 1 indicates a different understanding of HOMELAND. The first distinct difference is the use of expressions referring to other domains, as exemplified by the distinction of military and psychosocial aspects exclusively by Poles from Ukraine, as well as recording the ethical, ideological, religious ones by the Wroclaw and the Legni- obywateli, rodziny, bliskich, narodu oraz współmieszkańców, przy czym ci zostali odnotowani tylko raz. Konceptualizacja OJCZYZNY sprowadza się również do kompleksu wartości rozumianej jako kultura, historia, tradycja, rzadziej język. Ankietowani użyli także słów odnoszących się do deskryptorów zakwalifikowanych jako rozumienie instytucjonalne: państwo, obywatelstwo, prawo, rzadziej władza.

Ze zbioru 24 deskryptorów, które ze względu na niską liczbę wyrażeń nie zostały przedstawione $\mathrm{w}$ tym raporcie, warto odnotować powroty, dobre samopoczucie wymienione przez Polaków ze Lwowa i Mościsk, a także patriotyzm, język, społeczeństwo, do których nie odwołują się cytaty wydzielone z tekstów wywołanych, zebranych na Ukrainie.

\section{Cechy przypisywane 0JCZYŹNIE w ujęciu aspektowym. Profile ojczyzny}

Dla respondentów najważniejsza w wizji „prawdziwej” oJCZYZny okazała się sfera lokatywna, choć w przypadku Polaków z Polski obraz ten łączy się z wymiarem politycznym, o czym świadczą małe różnice dzielące dwa najliczniejsze aspekty (5,02 pkt proc.). Procentowy udział wyrażeń cytatowych poszczególnych aspektów zaprezentowany na wyk. 1. wskazuje na odmienne rozumienie oJCzyzNy. Pierwszą wyraźną różnicą jest użycie wyrażeń odnoszących się do innych domen, czego przykładem jest wyróżnienie aspektów militarnego i psychospołecznego wyłącznie przez Polaków z Ukrainy, jak również odnotowanie etycznego, ideologicznego, religijnego przez wrocławian i legniczan 


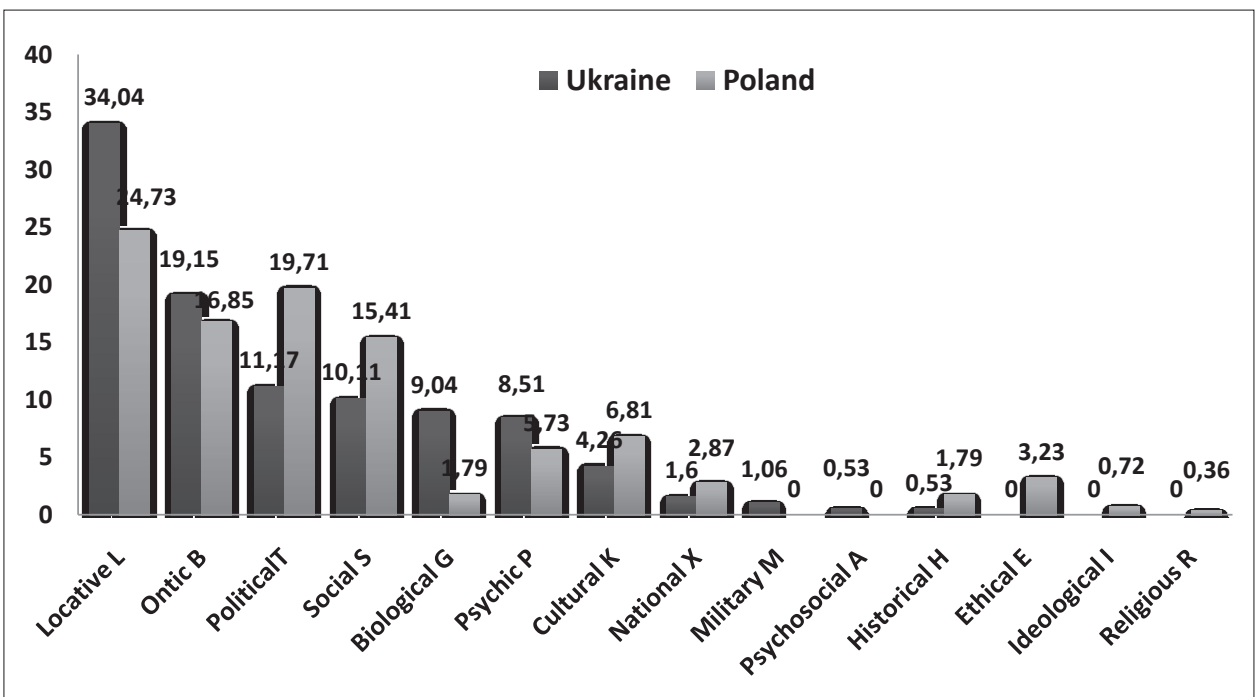

Figure 1. Features attributed to the homeland in terms of aspect (data expressed in \%) Source: own elaboration.

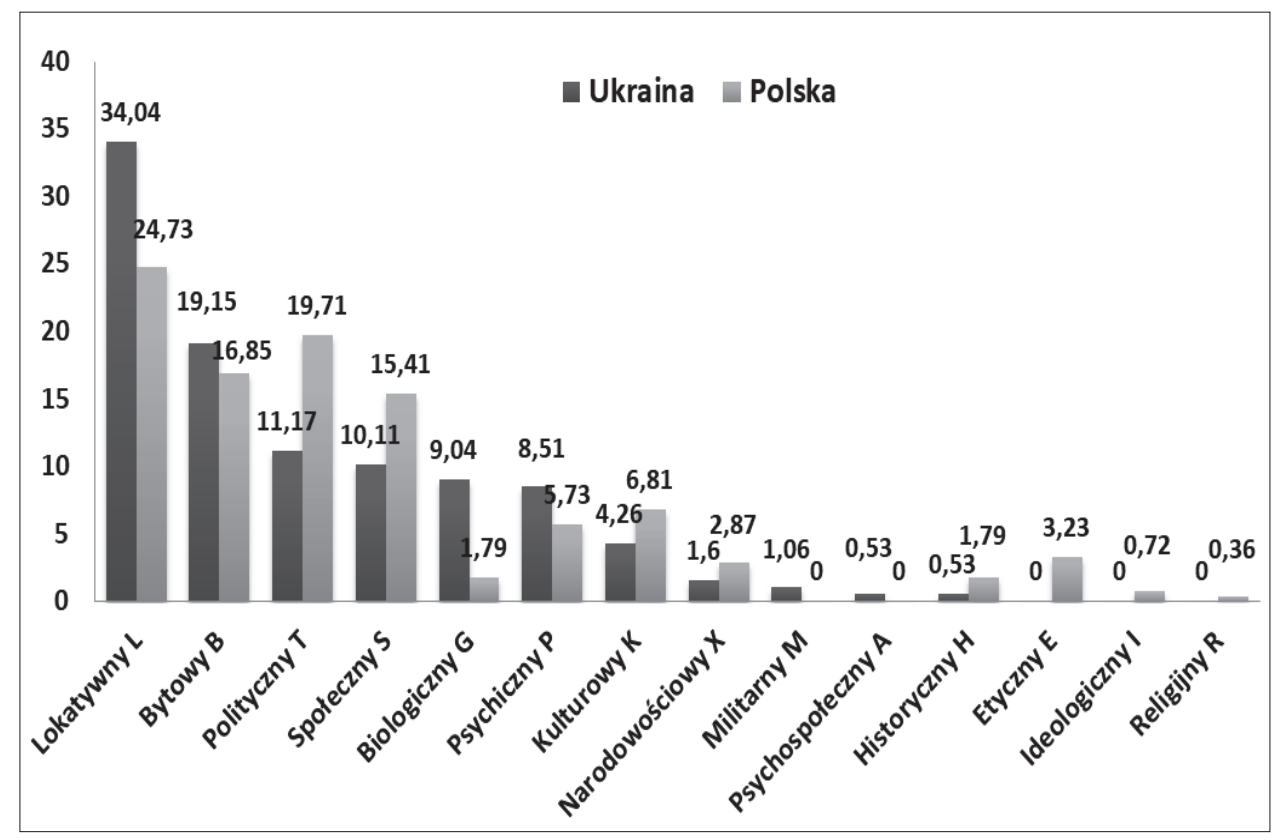

Wykres 1. Cechy przypisywane ojczyźnie w ujęciu aspektowym (dane wyrażone w \%) Źródło: opracowanie własne. 
ca inhabitants, when they were completely omitted by the respondents from Ukraine.

It is worth noting even emphases on four aspects - political, social, biological and psychological - to which $38.83 \%$ of the excluded expressions refer, and including the two most numerous aspects $92.02 \%$. In case of respondents holding citizenship of the Republic of Poland, there is no similar distribution of expressions. Four aspects of quantitatively related corpus collections, i.e., locative, political, ontic, social (76.7\% of quotations) are significantly different from the rest of the eight aspects.

Homeland can be classified as a circle of these concepts, in which it is possible to distinguish individual profiles created around the dominants e.g. home, world, nation. Jerzy Bartmiński claims that the basic profiles of a Polish homeland can be called due to the component to which the particular emphasis is placed, which becomes the semantic center, dominant. There are also seven dimensions of homeland: the home-family (OD), local (OL), regional $(\mathrm{OR})$, national $(\mathrm{ON})$, state $(\mathrm{OP})$, social $(\mathrm{OS})$, and culture $(\mathrm{OK})^{7}$.

Based on this division and the answers of the Poles surveyed, you can distinguish the dimensions of the homeland and the exemplary quotations related to the values of the six profiles:

1) home-family homeland: family home; where he/she feels safe; the land that gave birth to me; the land where [man] grew up; it is for me a state in which I feel good; 185. przy ich całkowitym pominięciu przez respondentów z Ukrainy.

Warto odnotować równomierne rozłożenie akcentów na cztery aspekty - polityczny, społeczny, biologiczny oraz psychiczny, do których odwołuje się 38,83\% wydzielonych wyrażeń, łącznie z dwoma najliczniejszymi aspektami - 92,02\%. W przypadku respondentów posiadających obywatelstwo Rzeczypospolitej nie zachodzi podobny rozkład wyrażeń. Cztery aspekty posiadające zbliżone pod względem ilościowym zbiory korpusów, tj. lokatywny, polityczny, bytowy, społeczny (76,7\% wyrażeń cytatowych), znacząco wyróżniają się na tle pozostałych ośmiu aspektów.

Ojczyznę można zaliczyć do kręgu tych pojęć, w ramach których wyróżniamy podmiotowe profile tworzone wokół dominant, np. dom, świat, naród. Jerzy Bartmiński twierdzi, że „podstawowe profile polskiej ojczyny możemy nazwać ze względu na to, na który składnik kładziony jest szczególny nacisk, który staje się semantycznym centrum, dominantą". Wyróżnia również siedem wymiarów ojczyzny: rodzinno-domową (OD), lokalną (OL), regionalną (OR), narodową (ON), państwową (OP), społeczną (OS), kulturową $(\mathrm{OK})^{7}$.

Wzorując się na tym podziale oraz odpowiedziach badanych Polaków, można wyróżnić wymiary ojczyzny oraz przykładowe wyrażenia cytatowe odnoszące się do wartości składających się na sześć profili:

1) ojczyzna rodzinno-domowa: rodzinny dom; tam, gdzie się czuje bezpiecznie; ziemia, która mnie zrodziła; ziemia, 185. 
2) local homeland: the land where my family and I live; nice friends; the land where my ancestors come from; people care about their place; the place where the wind sang me lullabies;

3) national homeland: we are its [land] children; acquired by the nation with its blood; I feel part of the nation; for its [country] freedom you can even give life; country that you love; every citizen is a patriot;

4) State homeland: a state in which everyone works for the success of his/her nation and state in the international arena; the state with boundaries, territory, government, law, citizens;

5) social homeland: I feel a bond with the society residing in its [state] borders; the state to which I belong by citizenship; feeling of belonging to each state;

6) cultural homeland: respect, esteem of customs and habits; country in which justice is in place; the country to which I belong by the same language; I know and I care about passing on centuriesold traditions. na której [człowiek] się wychował; jest dla mnie państwem, w którym dobrze się czuję;

2) ojczyzna lokalna: kraina, gdzie mieszka moja rodzina i ja;mili znajomi; kraina, z której pochodza moi przodkowie; ludzie dbaja o swoja miejscowość; miejscowość, w której wiatr śpiewał mi kotysanki;

3) ojczyzna narodowa: jesteśmy jej [ziemi] dziećmi; zdobyta przez naród swoja krwią; czuję się częścia narodu; za jej [ojczyzny] wolność może oddać nawet życie; kraj, który się kocha; każdy obywatel jest patriota;

4) ojczyzna państwowa: państwo, w którym każdy pracuje na sukces swego narodu i państwa na arenie międzynarodowej; państwo, które ma granice, terytorium, rzad, prawo, obywateli;

5) ojczyzna społeczna: czuję więź ze społeczeństwem zamieszkujacym w jego [państwa] granicach; państwo, do którego przynależe poprzez obywatelstwo; uczucie przynależności każdego człowieka do danego państwa;

6. ojczyzna kulturowa: respektowanie, szanowanie zwyczajów i obyczajów; kraj, w którym panuje sprawiedliwość; państwo, do którego przynależę poprzez ten sam jezzy; znam i dbam o przekazywanie wielowiekowych tradycji.

\section{Podsumowanie}

Końcowe zestawienie deskryptorów użytych przez wrocławian i legniczan wskazuje, że „prawdziwa” ojCzyzNa jest utożsamiana $\mathrm{z}$ krajem, państwem, miejscem 
residence of citizens and non-citizens attached to home, family and culture. They are connected by place of birth, common history, tradition, formal ties in the form of citizenship and laws in force within the borders of the state, as well as the goals of common good or unity. This value is also tied directly to Poland. It is distinguished, albeit less rarely, the perception of it in terms of psychic bond, nation, close people, adolescence, but also sacrifice, security, work.

On the other hand, for the inhabitants of Lvov and Mościska, the "real" номELAND is the country, the place of birth, the state of residence, the place of residence, the family to which he/she returns and feels attached. This concept also involves well-being, tradition, belonging to a political unit. The respondents from Ukraine identify HOMELAND primarily with the sphere of life, while relatively rarely refer to the characteristics typical of the HOMELAND within the meaning of the unit operating in the international legal space. With less frequency they emphasize issues related to the nation, the law, independence, citizenship.

Perhaps the influence on the lesser emphasis on the political sphere derives from the status of the respondents themselves, although in the area of the Lvov Consular Region there is a large group of Poles who have rights belonging to minorities, such as the possibility of teaching in Polish and even doubts of existential nature. Interviews conducted before the survey show that respondents from Lvov and Mościska feel simultaneously Poles and citizens of zamieszkania obywateli i nie-obywateli, przywiązanych do domu, rodziny, kultury. Są oni połączeni poprzez miejsce urodzenia, wspólną historię, tradycję, więzami formalnymi w postaci obywatelstwa i praw obowiązujących w granicach państwa, a także celami, jakimi są dobro wspólne czy jedność. Wartość ta jest również wiązana bezpośrednio z Polską. Wyróżnia się, choć rzadziej, pojmowanie jej w kategoriach więzi psychicznej, narodu, bliskich ludzi, dorastania, ale i poświęcenia, bezpieczeństwa, pracy.

Z kolei dla mieszkańców Lwowa i Mościsk „prawdziwa” oJCZYZnA jest krajem, miejscem urodzenia, państwem zamieszkania, gdzie znajduje się dom, rodzina, do którego się powraca i czuje przywiązanie. $Z$ pojęciem tym wiążą się również dobre samopoczucie, tradycja, przynależność do jednostki politycznej. Ankietowani z Ukrainy utożsamiają OJCZYZNĘ przede wszystkim ze sferą bytową, natomiast stosunkowo rzadko odwołują się do cech typowych dla ojCZYZNY w rozumieniu jednostki działającej w przestrzeni prawnomiędzynarodowej. Z mniejszą częstotliwością podkreślają kwestie związane z narodem, prawem, niepodległością, obywatelstwem.

Być może wpływ na mniejsze akcentowanie sfery politycznej wywodzi się ze statusu samych ankietowanych, mimo iż w rejonie Lwowskiego Obszaru Konsularnego żyje znaczna grupa Polaków mająca prawa przynależne mniejszościom, jak choćby możliwość nauczania w języku polskim, a także $\mathrm{z}$ wątpliwości natury egzystencjonalnej. $Z$ rozmów przepro- 
Ukraine (in a legal sense), which causes an internal tear between the two states. This question, apart from historical reasons such as ignorance of history and exaggerated simplification of facts, can be complicated by the sphere of identity qualification. On the other hand, in the consciousness of respondents from the Commonwealth, which is nationally practically homogeneous, the division into Poles-citizens and Poles-forced to live outside their homeland, is very much visible, leading to the identification of the latter group with third-country nationals, denying the status of a Pole or tendencies of renaming of a given community to Polonia status.

Virtually the only distinction between the two final reports is the number of citations, and especially the specific wealth in defining "true" hOMELAND by the respondents from the Commonwealth, although perhaps it is the consequence of only a slightly poorer language of Poles living behind the Eastern border of the Commonwealth or different curriculum in schools and colleges ${ }^{8}$. This is particularly evident in the section on institutional understanding, as exemplified by the fact that Ukrainian respondents did not use phrases referring to power, borders or justice. Despite the differences in the number of features, there is the impression that the remaining descriptors are essentially related to the same feelings or phenomena.

${ }^{8}$ Respondents from Lvov and Mościska in the year of my research were 16 years old, in Poland, due to another educational organization, the age limit is slightly higher. wadzanych przed badaniem wynika, że respondenci ze Lwowa i Mościsk czują się jednocześnie Polakami i obywatelami Ukrainy (w sensie prawnym), co powoduje wewnętrzne rozdarcie między dwa państwa. Kwestię tę, prócz względów historycznych, takich jak nieznajomość dziejów i przesadne upraszczanie faktów, może komplikować sfera kwalifikacji tożsamościowej. Natomiast w świadomości respondentów z Rzeczypospolitej będącej państwem pod względem narodowościowym praktycznie jednolitym, bardzo mocno zarysowuje się podział na Polaków-obywateli i Polaków-zmuszonych do życia poza ojczyzną, co prowadzi do utożsamienia tej drugiej grupy z obywatelami państw trzecich, odmawiania statusu Polaka czy tendencji przemianowania danej społeczności do statusu Polonii.

Praktycznie jedynym rozróżnieniem obu końcowych raportów jest liczba wyrażeń cytatowych, a zwłaszcza swoiste bogactwo w definiowaniu „prawdziwej” oJCZYZNY przez respondentów z Rzeczypospolitej, choć być może jest to następstwo jedynie nieco uboższego języka Polaków żyjących za wschodnią granicą Rzeczypospolitej lub innego programu nauczania w szkołach i uczelniach wyższych ${ }^{8}$. Jest to szczególnie widoczne w części dotyczącej rozumienia instytucjonalnego, czego przykładem niech będzie to, że ankietowani z Ukrainy nie użyli zwrotów odnoszących się do władzy, granic czy sprawiedliwości. Pomimo różnic w liczbie cech, odno-

8 Respondenci-maturzyści ze Lwowa i Mościsk w roku przeprowadzania przeze mnie badań mieli 16 lat, w Polsce, ze względu na inną organizację szkolnictwa, granica wieku jest nieco wyższa. 
In addition, in the group of ten descriptors ${ }^{9}$ referenced by the highest number of quotations separated from the answers of Poles from Poland and Ukraine, up to seven meta-expressions are found in both sets: country, place, state, residence, home, family, attachment. On the other hand, the first five, apart from the hierarchy, differ only in one descriptor - birth on the Ukrainian side and citizen on the Polish side. As this juxtaposition shows, the essence of the "true" HOMELAND, which consists of the most descriptors, for the citizens of the Commonwealth and holders of the Pole's Card is practically the same. The differences are revealed only in subsequent, less numerous meta-expressions indicating a richer conceptualization, mainly related to the specific space and institutional understanding of this value.

\section{Abstract}

The article shows the conceptualization of concept HOMELAND - results of the survey conducted on a group of young Poles living in Lvov, Mościska (Mostyska), Wrocław and Legnica. The aim of this research is comparison of the understanding of HOMELAND by Poles living in different countries. The article consists of two parts: the first presents

9 The ten most frequent descriptors from the report depicting the true origin of the true HOMELAND by the respondents from Lvov and Mościska: country, place, birth, state, residence, home, family, returns, attachment, well-being. The ten most frequent descriptors from the report presenting the perception of true HOMELAND by the respondents from Wrocław and Legnica: country, state, residence, place, citizen, people, attachment, home, family, culture. si się wrażenie, że pozostałe deskryptory w gruncie rzeczy wiążą się z tymi samymi odczuciami czy zjawiskami.

Ponadto w grupie dziesięciu deskryptorów ${ }^{9}$, do których odwołuje się najwyższa liczba wyrażeń cytatowych wydzielonych z odpowiedzi Polaków z Polski i Ukrainy, aż siedem metawyrażeń znajduje się w obu zbiorach: kraj, miejsce, państwo, zamieszkanie, dom, rodzina, przywiązanie. Pierwsze pięć zaś, prócz hierarchii, różni się tylko jednym deskryptorem urodzenie po stronie ukraińskiej i obywatel po stronie polskiej. Jak pokazuje to zestawienie, istota "prawdziwej” oJCzyZNY, na którą składają się najliczniejsze deskryptory, dla obywateli Rzeczypospolitej i posiadaczy Karty Polaka jest praktycznie taka sama. Różnice ujawniają się dopiero w kolejnych, mniej licznych metawyrażeniach wskazujących na bogatszą konceptualizację, odnoszącą się w głównej mierze do określonej przestrzeni i rozumienia instytucjonalnego tej wartości.

\section{Abstrakt}

Artykuł prezentuje konceptualizację pojęcia OJCZYZNY stanowiącą opracowanie wyników badań ankietowych przeprowadzonych na grupie Polaków mieszkających we Lwowie, Mościskach, Wrocławiu i Legnicy, mających na celu zestawienie sposobów rozumienia oJCZYZNY przez Polaków funkcjonujących w różnych państwach.

9 Dziesięć najliczniejszych deskryptorów z raportu przedstawiającego pojmowanie prawdziwej ojczyzny przez respondentów ze Lwowa i Mościsk: kraj, miejsce, urodzenie, państwo, zamieszkanie, dom, rodzina, powroty, przywiązanie, dobre samopoczucie. Dziesięć najliczniejszych deskryptorów $\mathrm{z}$ raportu przedstawiającego pojmowanie prawdziwej OJCZYZNY przez respondentów z Wrocławia i Legnicy: kraj, państwo, zamieszkanie, miejsce, obywatel, ludzie, przywiązanie, dom, rodzina, kultura. 
a description of the research method used by a team of linguists working under Prof. Jerzy Bartmiński's leadership, which I used working on the second part, compiling the respondents' answers.
Tekst składa się z dwóch części: w pierwszej został przedstawiony opis metody zastosowanej w badaniu wartości przez zespół lubelskich lingwistów, pracujących pod kierownictwem prof. Jerzego Bartmińskiego, którą posłużyłam się przy opracowaniu części drugiej, zestawiającej odpowiedzi respondentów.

\section{Bibliography / Bibliografia}

Bartmiński J., Jęzkowe podstawy obrazu świata, Lublin 2012.

Blacksell M., Geografia polityczna, transl. J. Halbersztat, Warszawa 2008.

Język - wartości - polityka: zmiany rozumienia nazw wartości w okresie transformacji ustrojowej w Polsce. Raport z badań empirycznych, edit. J. Bartmiński, Lublin 2006.

Pojęcie ojczyzny we wspótczesnych językach europejskich, edit. J. Bartmiński, Lublin 1993.

Article submitted: 14.11.2016; article accepted: 12.02.2017 